\title{
Late Miocene-Pleistocene tectono-sedimentary evolution and subsidence history of the central Betic Cordillera (Spain): a case study in the Guadix intramontane basin
}

\author{
J. M. SORIA*, C. VISERAS†† \& J. FERNÁNDEZ† \\ * Departamento de Ciencias de la Tierra, University of Alicante, Apdo. 99 Alicante, Spain \\ $\dagger$ Departamento de Estratigrafía y Paleontología, University of Granada, 18071-Granada, Spain
}

(Received 25 November 1997; accepted 11 March 1998)

\begin{abstract}
The Guadix Basin became established as an intramontane basin in the central sector of the Betic Cordillera at the beginning of Late Miocene time. Its geodynamic evolution starts with a unit of Tortonian marine sediments and is completed by a unit of Late Turolian-Pleistocene continental sediments. In the two units, six depositional sequences have been differentiated whose boundaries, in most cases, coincide with tectonic events. Geohistorical diagrams show the results of quantitative analyses of subsidence in the northern sector of the basin and permit correlation of the main events with significant changes in the history of subsidence and uplift. A period of strong subsidence occurred at the beginning of Tortonian time causing the formation of a marine basin $800 \mathrm{~m}$ deep. The mid- and endTortonian tectonic events involved periods of uplift leading to shallowing in the basin. After continentalization at the end of the Tortonian, the basin was uplifted continuously from Late Turolian to Late Pleistocene times, finally accumulating sediments at a height of $1000 \mathrm{~m}$.
\end{abstract}

\section{Introduction}

A large amount of information is at present available on the sedimentary filling of the Tertiary basins in the Iberian Peninsula as a whole (e.g. Friend \& Dabrio, 1996). However, considerable interest has arisen in the basins associated with the Neogene-Quaternary deformation and evolution of the Betic Cordillera. An example is the recent completion of Leg 161 of the Ocean Drilling Programme (Comas et al. 1996) on the only still-submerged sedimentary basin of the Betic Cordillera (Alboran Basin), with the object of further extending the field-based studies. However, the large amount of tectonic and stratigraphic information on the Betic intramontane basins contrasts with the scarcity of quantitative data on vertical movements undergone by these basins throughout their evolution, for which the only contributions refer to the basins of the eastern sector of the Cordillera (Cloetingh et al. 1992; De Ruig, 1992; Janssen et al. 1993).

A number of recent papers (e.g. Viseras \& Fernández, 1992; Fernández, Bluck \& Viseras, 1993; Soria, 1994; Fernández, Soria \& Viseras, 1996; Fernández, Viseras \& Soria, 1996) describe the basic stratigraphic architecture necessary to undertake an analysis of subsidence and uplift in the basins of the central sector of the Betic Cordillera. For this purpose, we chose the Guadix Basin, as it has a thick filling of both marine and continental sediments stretching from the Late Miocene to the Quaternary with no

† Author for correspondence: viseras@goliat.ugr.es appreciable gaps. The striking variations in palaeobathymetry and palaeoelevation recorded in the filling make this basin a suitable setting in which to measure subsidence and uplift in the central sector of the basin since: (1) it has the most complete stratigraphic successions, (2) it has been the subject of recent stratigraphic and sedimentological studies which establish fairly exhaustively its stratigraphic architecture (Viseras, 1991; Soria, 1994; Fernández, Soria \& Viseras, 1996; Fernández, Viseras \& Soria, 1996), (3) its sedimentary features related to the activity of different autocyclic and allocyclic control mechanisms are well known (Fernández, Bluck \& Viseras, 1991, 1993; Viseras \& Fernández, 1994, 1995) and (4) it constitutes an exceptional example of the geological record of uplift in this sector of the Cordillera up to even very recent times (Viseras \& Fernández, 1992; Calvache, Viseras \& Fernández, 1996; Calvache \& Viseras, 1997).

This paper therefore provides the first quantitative data on vertical movements in the central sector of the Betic Cordillera. The results are included in a scheme of tectono-sedimentary evolution in order to estimate the relative role of the different events controlling the geodynamic history of the area. Our intention is that the procedures applied here may serve as a methodological reference for other studies on intramontane basins in the Betic Cordillera.

\section{Geological setting}

Together with the Rif (North Africa), the Betic Cordillera (southern Iberia) represents the westernmost 
element of the peri-Mediterranean Alpine chains arising out of the closure of the Tethys due to convergence of the African and Eurasian plates (Sanz de Galdeano, 1990). It basically consists of two structural domains: to the south the Internal Zones or Alboran Block (Andrieux, Fontboté \& Mattauer, 1971) and to the north the External Zones or South-Iberian Palaeomargin (Comas \& García Dueñas, 1988). Both domains underwent convergence and collision until the Early Miocene, which led to significant thickening of the crust. This compressive phase was followed by an extensional phase dominated by detachment movements that played a decisive role in the development and evolution of the sedimentary basins (García Dueñas, Balanyá \& Martínez, 1992; Jabaloy, Galindo Zaldívar \& González Lodeiro, 1992).

One of these is the Guadix Basin, located in the central sector of the Betic Cordillera (Fig. 1) and sealing the contact between the Internal and External Zones. It is an intramontane basin established as such in the Late Miocene, after the main tectonic movements that shaped the large structures of the Betic Orogen (see, e.g. Sanz de Galdeano \& Vera, 1992). Sedimentation in the basin began in Tortonian time, after the dismantling of the North-Betic Strait (an ancient seaway between the Atlantic and Mediterranean marine domains to the north of the cordillera). The basin ceased to exist in the Late Pleistocene, when its endorheic filling stage ended (J. Soria, unpub. Ph.D. thesis, Univ. Granada, 1993). Since then the whole area occupied by the basin has been captured by the drainage network of the Guadalquivir River, becoming an erosional domain with the loss of much of its filling (Calvache \& Viseras, 1997).

\section{Tectono-sedimentary synthesis}

All the stratigraphic units recognized in the basins of the central sector of the Betic Cordillera crop out in the northern part of the Guadix Basin (Fig. 1) lying on the Subbetic basement (External Zones). In addition, this is a zone in which the main tectonic features typifying its deformational style are represented.

The sedimentary filling of this basin (and, in general, of the basins located in the central sector of the Betic Cordillera) has been divided into six stratigraphic units bounded by unconformities at basin scale (Soria, 1994; Fernández, Soria \& Viseras, 1996), to which we refer as depositional sequences (sensu Mitchum, Vail \& Thomson, 1977). In most cases, the boundaries between such sequences represent tectonic events related to different phases of fracturing and folding and responsible for noticeable alterations in the position of the basin as regards sea level. These recently defined sequences contain a number of lithostratigraphic units formally differentiated in previous papers (Vera, 1970; Viseras \& Fernández, 1988; J. Soria, unpub. Ph.D. thesis, Univ. Granada, 1993) and whose situation in the new stratigraphic architectural scheme is summarized in Figure 2. There follows a

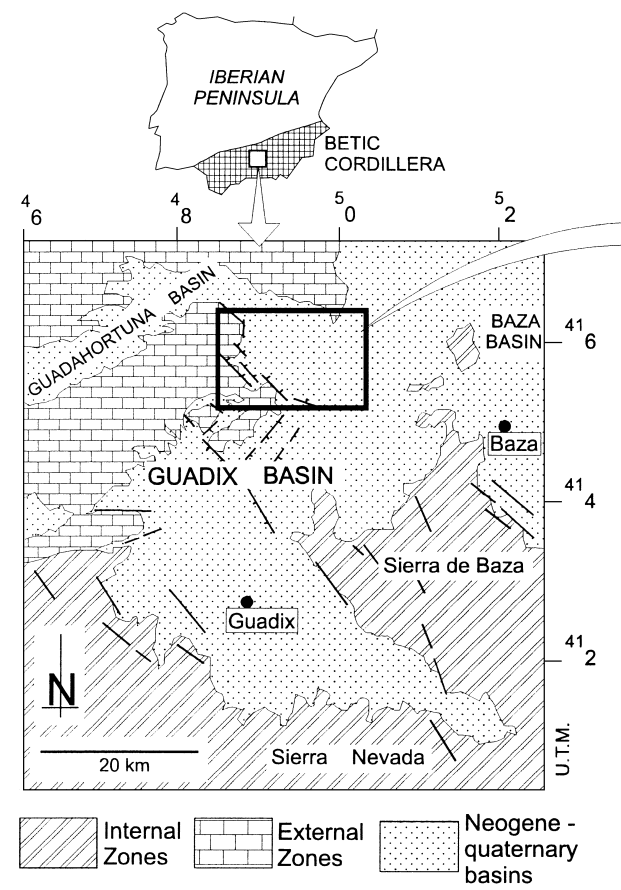

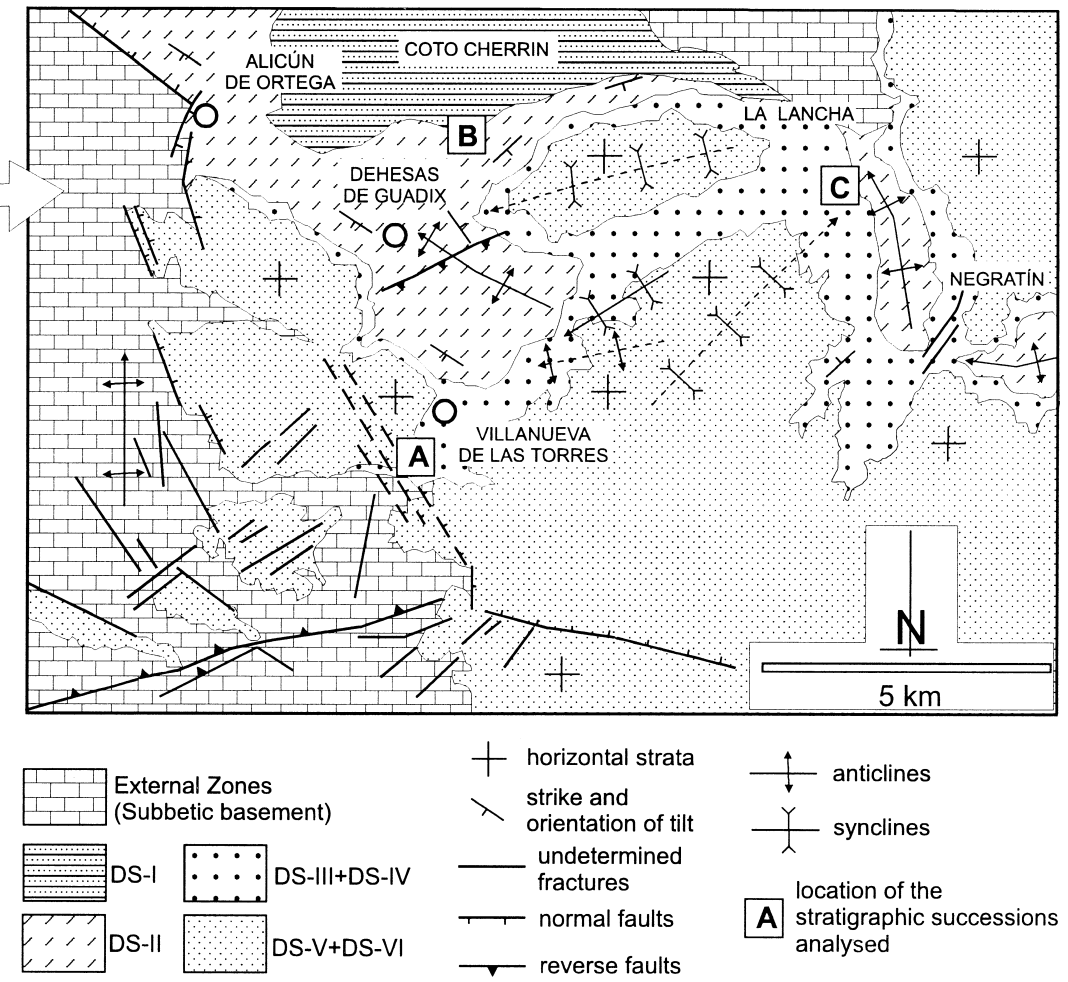

Figure 1. Location of the Guadix Basin in the Betic Cordillera and cartographic scheme of the northern margin of the Guadix Basin. 


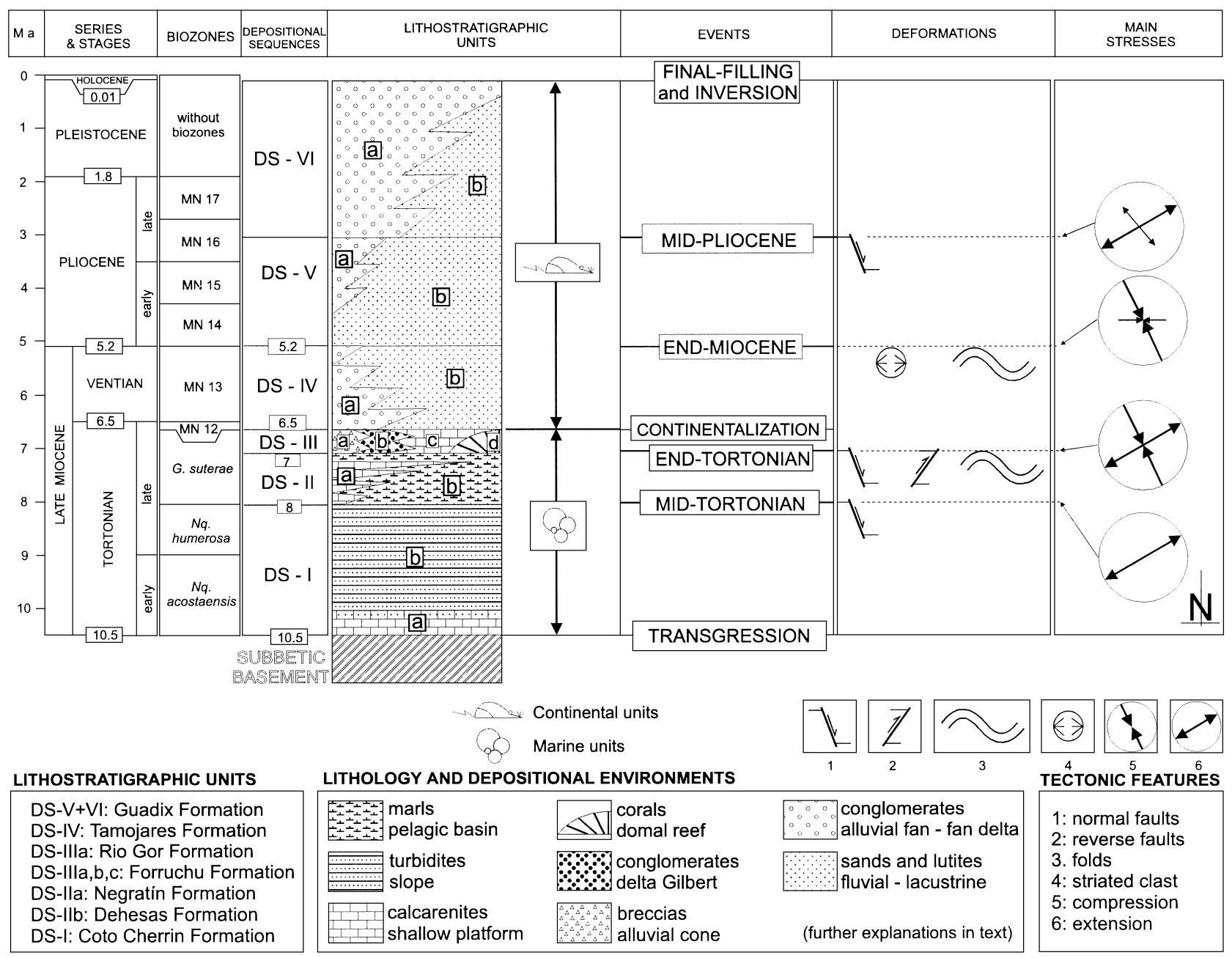

Figure 2. Stratigraphic and tectonic synthesis of the northern sector of the Guadix Basin.

description of the main features allowing sedimentary characterization and the tectonic context for the period of development of each sequence. The two lower sequences correspond to the marine sedimentation stage, the third includes the sediments deposited during marine withdrawal from the central sector of the Betic Cordillera, and the last three represent the stage of exclusively continental sedimentation.

\section{3.a. Marine filling}

\section{3.a.1. Depositional sequence I (DS-I)}

This sequence, dating from Early Tortonian times ( $N q$. acostaensis zone) and the early part of Late Tortonian times ( $N q$. humerosa zone), consists of two units, one gradually replacing the other in vertical succession. At the base, the limestone member (DS-Ia) lies unconformably on the Subbetic basement and consists of massive bioclastic calcarenites. The major components are red algae, bivalves, bryozoa, echinoderms and benthic foraminifers (Elphidium, Bulimina and Cibicidoides). This member corresponds to the most internal part of a shallow marine platform. The marly- sandstone member (DS-Ib) overlies the former and is represented by a thick set of turbidites organized in Bouma sequences ( $\mathrm{Ta}$ and $\mathrm{Tab}$ ) and sequences of liquified-fluidized flows, which are both characteristic of a slope environment. The interturbiditic marls show predominance of planktonic over benthic foraminifers in a ratio of approximately 10:1. The lower boundary of DS-I represents a transgressive event on the topography of the Subbetic basement. The vertical evolution of the facies reflects the establishment of gradually deeper marine conditions.

\section{3.a.2. Depositional sequence II (DS-II)}

This sequence is made up of two units (DS-IIa and DS-IIb) dating from the latest Tortonian (G. suterae zone) that are lateral facies equivalents. DS-IIa was deposited unconformably on the Subbetic basement in marginal areas of the basin and consists of bioclastic calcarenites with bivalves, bryozoa, Balanus, red algae, fish teeth and benthic foraminifers, all biofacies typical of an internal marine platform. DS-IIb was deposited in central areas of the basin in paraconformity with DS-Ib. It consists of grey-blue marls in which vertical 
gradation of lithofacies and biofacies can be observed. In the lower part, therefore, the marls have faint terrigenous contamination, abundant hyalosponges and a ratio of planktonic to benthic foraminifers of approximately $7: 1$. In the upper part the sand fraction content is higher, to the extent of there being turbidite layers distorted by slumps; the planktonic to benthic foraminiferal ratio is approximately 1:2 and there are numerous scaphopods (Dentalium), echinoderms, ostracods, fish scales and moulds of small bivalves. All these data suggest gradual shallowing of facies throughout the development of DS-IIb within the deep zone of a basin dominated by pelagic sedimentation. The beginning of DS-II coincides with the midTortonian tectonic event, during which the first extensional fracture systems formed on the basin margins. The same event also produced an important alteration of the depositional environments in space and time. After this event, the marginal sectors of the basin were differentiated by shallow marine platform sediments (DS-IIa) for the first time.

\section{3.b. Marine-continental transition: Depositional sequence III (DS-III)}

The age of this sequence has been established as latest Tortonian (G. suterae zone). Its lower boundary is an erosive unconformity beneath which DS-IIb is found in most outcrops, although sequences DS-IIa, DS-I and the basement of the External Zones and, in southern sectors of the basin, the basement of the Internal Zones can be found. The maximum thickness is $15 \mathrm{~m}$, with facies varying widely from one part of the basin to another, although a concentric zonation of four units can be established. The outermost of these (DSIIIa) is characterized by the superposition of lenticular sedimentary bodies built up by debris flow, mud flow and scree in subaerial conditions. The three remaining units of the sequence were deposited beneath sea level. DS-IIIb is characterized by a predominance of coarse clastic facies, mainly conglomerates with brachiopods, Balanus and boring bivalves (lithofaga) and its internal organization consists of large prograding clinoforms interpreted as the foreset and bottomset of Gilbert-type deltas. DS-IIIc is a calcarenitic unit deposited in central sectors with predominance of calcarenites and bioclastic calcirudites containing abundant fragments of red and green algae, bryozoa, echinoderms, bivalves and benthic foraminifers; planktonic foraminifers are considerably less abundant. A reef unit (DS-IIId) is associated with this facies and consists of coral bioherms (Porites and Tarbellastrea) with a typical domed shape. The reefal taluses are particularly well exposed mainly with breccias (rudstones) and sands with wave ripples (grainstones). The three underwater units of this sequence (DS-IIIb, c and d) were deposited in extremely shallow seas, possibly even in the area of wave activity. The base of this sequence marks the conclusion of the endTortonian tectonic event which produced folds and fractures in the previous units. We consider this event also responsible for the sharp decrease in depth in the central parts of the basin and the emergence of its marginal areas.

\section{3.c. Continental filling}

After the Late Turolian, the basins located in the central sector of the Betic Cordillera remained cut off from the sea and developed a palaeogeographic pattern of axial drainage (a coarse-grained meandering fluvial system throughout most of its course) and two transverse drainage systems from the Internal and External Zones, corresponding to different types of alluvial fan and fan delta (see, e.g. Viseras, 1991; Fernández, Bluck \& Viseras, 1993; Viseras \& Fernández, 1994, 1995). At times the progradation of the transverse fans came to obstruct the master drainage, leading to partial occupation of the axial valley by ephemeral lakes. Over the almost $7 \mathrm{Ma}$ of the continental stage, these lakes underwent important variations in size mainly due to climatic changes. Periods can be identified when lacustrine sedimentation disappeared and playa-lake conditions existed.

Continental infilling can be divided into three sequences. In order to simplify the analysis of subsidence, we shall deal with the lower sequence (DS-IV) separately from the two more recent ones (DS-V and DS-VI) since the former was deposited under a different tectonic regime to the latter (Fig. 2).

\section{3.c.1. Depositional sequence IV (DS-IV)}

This sequence developed from the Late Turolian (zone MN 12) to the Ventian (zone MN 13). In the study area it is represented by the conglomerate sediments of the transverse drainage system from the External Zones (DS-IVa) which changes facies near the centre of the basin to lutitic sediments with intercalations of palaeosols and layers of more carbonate, intensely bioturbated sediments containing freshwater fossils (gastropods and characea) that correspond to the palustrine ring around one of the lakes on the axial valley (DS-IVb). In the study area unit DS-IVa lies unconformably on the basement of the External Zones, whereas unit DS-IVb lies unconformably on both DS-III and DS-II. From a palaeoenvironmental viewpoint, it has been interpreted as an alluvial fan-fan delta system connecting towards the northeast with the mud flat corresponding to the palustrine ring of the lake (Fernández, Bluck \& Viseras, 1993).

\section{3.c.2. Depositional sequences $V$ and VI (DS-V+VI)}

The lower limit of DS-V is the so-called end-Miocene tectonic event (Fig. 2) that caused generalized folding 
leading to striation of clasts in the detrital units of the preceding sequences. The boundary between DS-V and DS-VI was also the result of a tectonic event detectable in the basement of the Internal Zones at the beginning of the Late Pliocene (zone MN 16) that increased the drainage area of the fans on the southern margin of the basin and caused a rapid decrease in subsidence rate (Viseras, 1991). In consequence there was a rapid northward displacement of the palaeogeographic axis of the basin, represented by the axial fluvial system and associated lakes. This mid-Pliocene tectonic event resulted in a stratigraphic boundary between DS-V and DS-VI, which is an unconformity towards the basin margins but conformable towards the centre with no appreciable stratigraphic gap.

Another distinguishing feature of DS-V and DS-VI compared with DS-IV is that they had a lower accumulation rate, which, together with the sharp climatic changes occurring since the Pliocene, suggests that these sequences record very rapid changes of the boundaries between the different sedimentary systems described above (axial fluvial, transverse alluvial and lacustrine) with the subsequent flattening of the changing facies surfaces between them (Viseras, 1991).

Concerning the facies in the study area, they are the same as those of DS-IV, that is, coarse sediments corresponding to alluvial fans and fan deltas (DS-Va and DS-VIa) predominate near the basin margins, whereas towards the centre we find the sandy sediments of the axial system or lutitic-carbonate (occasionally evaporitic) sediments of lacustrine origin (DS- $\mathrm{Vb}$ and DS-VIb).

The sedimentation of DS-VI ended in conditions of very low accumulation rate, leading to the event we refer to as topping-up that occurred between 100000 and 16300 years B.P. (Calvache \& Viseras, 1997), immediately before the basin inversion that initiated the erosive stage. When basin inversion took place the last episodes of basin filling occurred at approximately $1000 \mathrm{~m}$ above sea level.

\section{Subsidence history: successions analysed and analytical method}

In order to illustrate the history of subsidence and uplift in the study area we have chosen three stratigraphic successions (Fig. 1), each recording different histories of environmental change (Fig. 3). The successions of Villanueva de las Torres (A) and La LanchaNegratín (C) are typical of marginal sectors of the basin during the periods of marine sedimentation, whereas the Coto Cherrín-Dehesas de Guadix succession (B) is characteristic of the deepest sector of the basin.

Subsidence or uplift were calculated for each of the successions described above. This was done using the 'Backstripping' programme (Allen \& Allen, 1990) based on algorithms proposed by Sclater \& Christie
(1980) and Bond \& Kominz (1984). This programme calculates total subsidence, decompacting the stratigraphic units and tectonic subsidence by eliminating the effects of sedimentary load, for which it assumes an Airy-type model of local isostatic compensation. The necessary data on porosity, coefficient of porosity decrease with depth and density of sediments were taken from the standard values proposed for different lithological types by Gallagher \& Lambeck (1989).

The 'Backstripping' programme permits the introduction of palaeobathymetric corrections, thus obtaining values of total and tectonic subsidence in relation to a fixed datum (sea level). Graphic representation of these values is given in geohistorical diagrams (Fig. 4), following the models described by Van Hinte (1978) and Angevine, Heller \& Paola (1990). These geohistorical diagrams were then used to calculate the rates of subsidence and sediment accumulation (Fig. 5).

\section{4.a. Corrections of palaeobathymetry and palaeoelevation}

The final results of total and tectonic subsidence depend to a large extent on the corrections of palaeobathymetry and palaeoelevation. We therefore offer an explanation of the criteria used to determine these parameters in each stratigraphic unit.

The palaeobathymetry (see Fig. 3) of the marine stratigraphic units represented in the three successions studied here was determined by analysis of biofacies. In the marine units with predominantly pelagic sedimentation (DS-Ib and DS-IIb), the criterion used was the ratio between planktonic and benthic foraminifers. Comparison with the detailed study by Berggren \& Haq (1976) on this aspect of Late Miocene sediments in the nearby Guadalquivir Basin allows us to estimate palaeobathymetry of 600 to $1000 \mathrm{~m}$ for DS-Ib, with an average value of $800 \mathrm{~m}$, and in the case of DS-IIb an average value of $800 \mathrm{~m}$ for the lower part and $300 \mathrm{~m}$ for the upper part. For the units with shallow marine sedimentation (DS-Ia, DS-IIa and DS-III) we used the bathymetric limits proposed by Heckel (1972) and Gradstein \& Srivastava (1980) on the basis of assemblages of benthic foraminifers and other organisms such as red algae, hyalosponges, hermatypic corals, bryozoa, Balanus and lithofaga. The maximum palaeobathymetry of both DS-Ia and DS-IIa is therefore $20 \mathrm{~m}$, whereas the marine part of DS-III had an average palaeobathymetry of $10 \mathrm{~m}$.

It is hard to determine the palaeoelevation of the continental units by direct criteria. Indeed, a topographic elevation cannot be calculated on the basis of analyses of fluvial or palustrine sediments. However, there are two known data in the Guadix Basin that can be used for this purpose: (1) the start of continental sedimentation at the bottom of DS-IVb, which allows us to assume a palaeoelevation of $0 \mathrm{~m}$ for this position, and (2) the end of sedimentation of DS-V+VI 


\section{VILLANUEVA DE LAS TORRES}

COTO CHERRIN -

DEHESAS DE GUADIX
LA LANCHA NEGRATIN
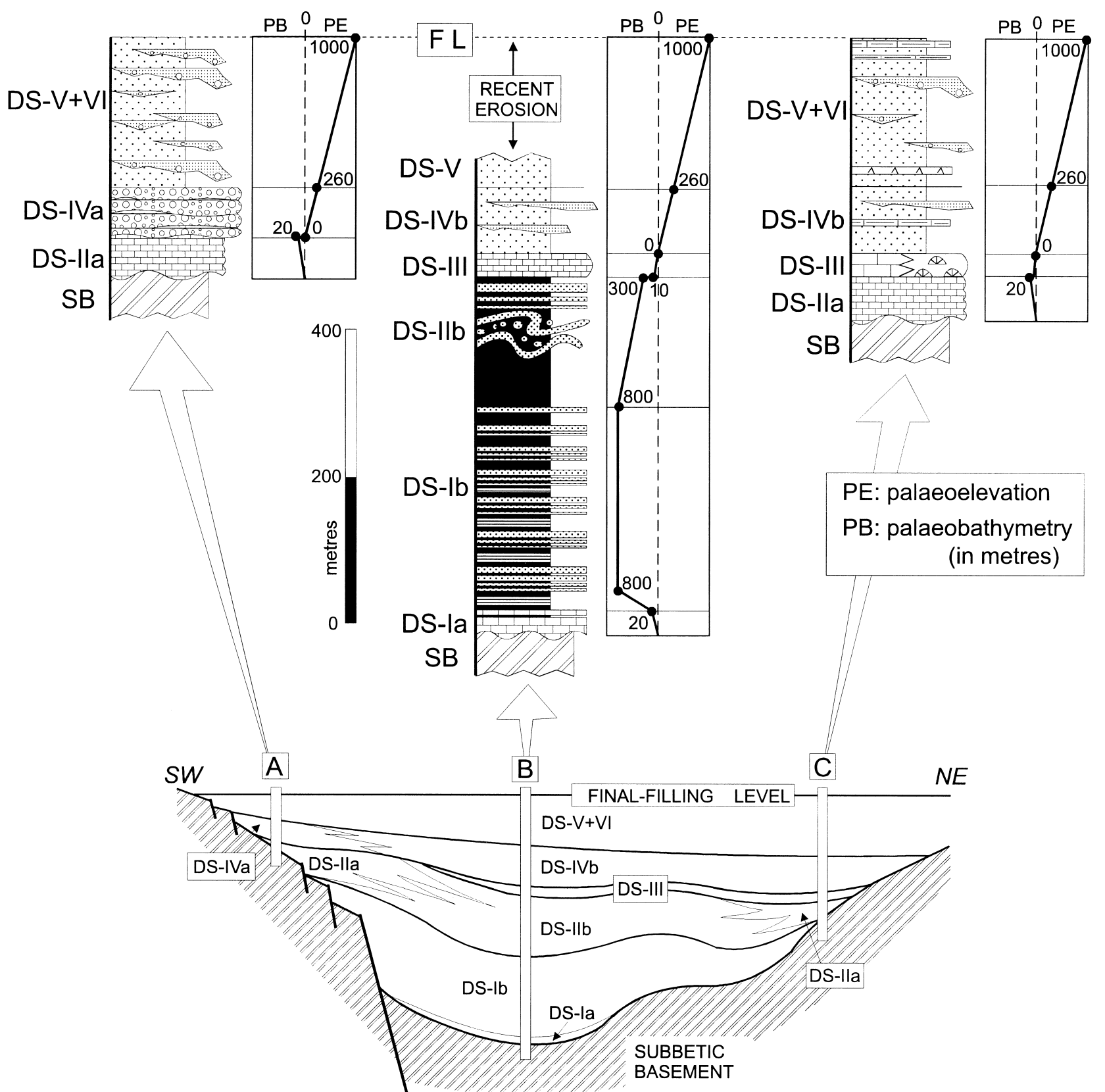

B

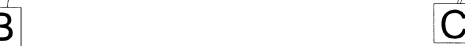

PE: palaeoelevation

PB: palaeobathymetry (in metres)

\section{LEGEND FOR THE STRATIGRAPHIC SUCCESSIONS}

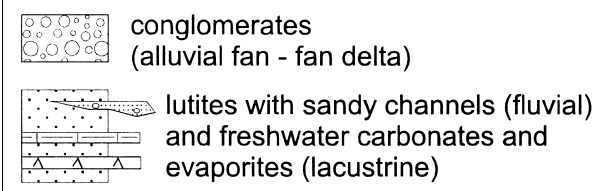

Figure 3. Stratigraphic successions chosen for quantitative analysis of subsidence and uplift. The lower drawing shows the geometry of the depositional sequences in the study area.

with deposition in the basin at $1000 \mathrm{~m}$. These two values therefore mark the beginning and end of continental sedimentation (see Fig. 3). We can now infer the palaeoelevation of the boundary between DS-IV and DS-V which, assuming continuous uplift between continentalization and final-deposition, would be $260 \mathrm{~m}$. 

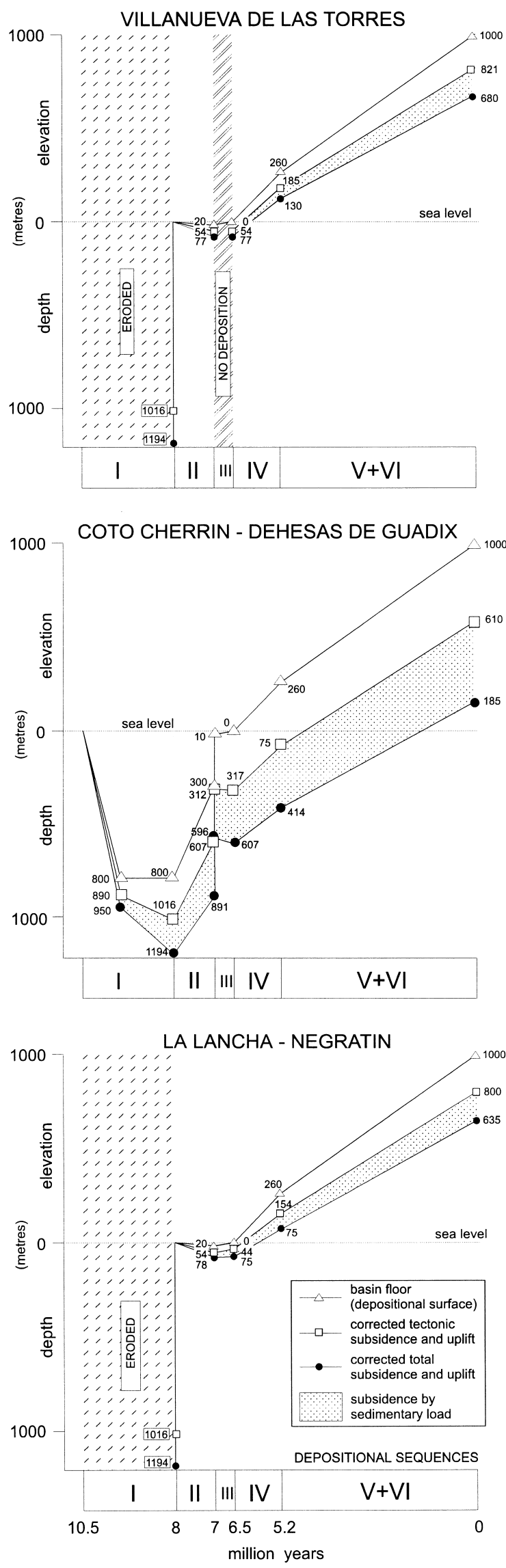

Figure 4. Geohistorical diagrams of the three stratigraphic succession studied.
5. Integration of the results of the subsidence history in the geodynamic evolution of the basin

The results of the tectono-sedimentary evolution and the quantitative analyses of subsidence and uplift can be integrated into a combined scheme of geodynamic evolution as shown in Figure 6. The main events occurring in the northern sector of the Guadix Basin were as follows.

A transgressive event on the Subbetic basement in the earliest Tortonian marks the beginning of sedimentation in the Guadix Basin. From this moment on, there was a stage of intense subsidence with an overall rate of $0.48 \mathrm{~mm} / \mathrm{a}$, that led to the formation of a marine basin $800 \mathrm{~m}$ deep, in which DS-I was deposited in a slope context dominated by gravitational processes. According to Soria (1994) this slope occupied the whole area studied here, including the Villanueva de las Torres and La Lancha-Negratín sectors.

The mid-Tortonian tectonic event caused a rapid rise of these two sectors, where the continental slope deposits of DS-I were completely eroded and where the basement emerged and was thus subjected to erosion. Deposition of DS-II began after this tectonic event

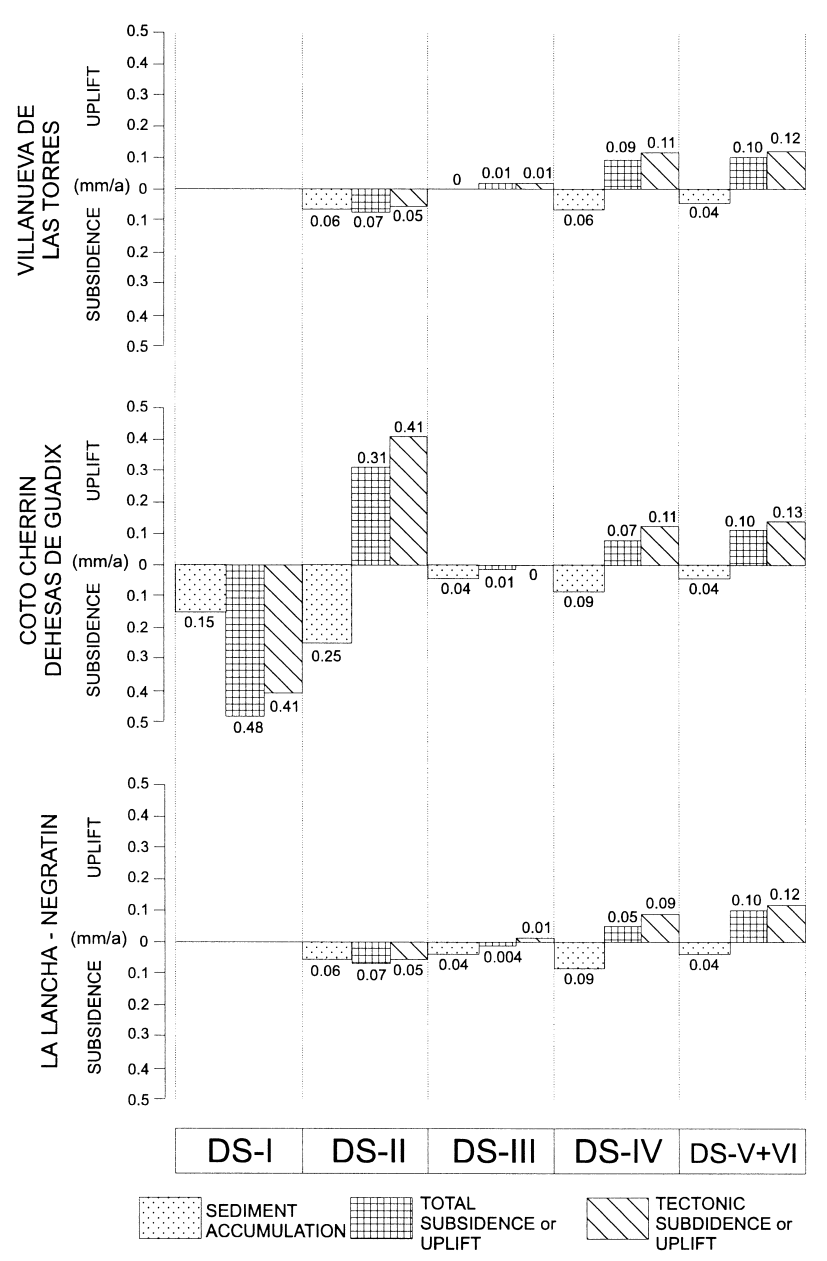

Figure 5. Bar chart showing rates of accumulation, total subsidence and uplift, and tectonic subsidence and uplift. 


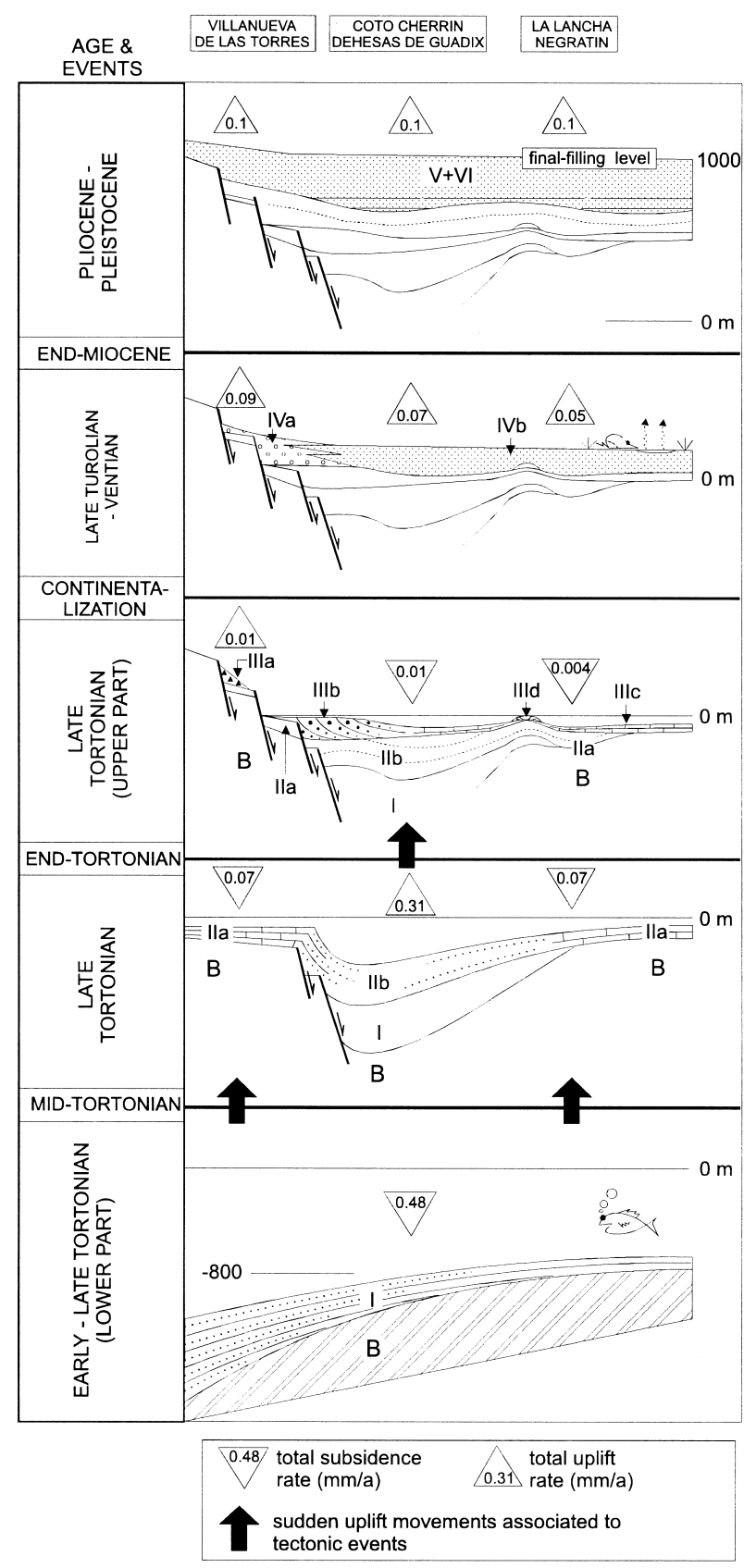

Figure 6. Geodynamic evolution of the northern margin of the Guadix Basin: integration of results on tectonosedimentary evolution and quantitative analysis of subsidence and uplift.

that significantly changed the sedimentation pattern of DS-I. During the deposition of DS-II a basin with shallow marine platforms (DS-IIa) became defined in the Villanueva de las Torres and La Lancha-Negratín sectors. The deepest part of this basin, with predominantly pelagic sediments (DS-IIb) was located in the Coto Cherrín-Dehesas de Guadix sector. The shallow marine platform sectors recorded slight subsidence during deposition, with total rates of $0.07 \mathrm{~mm} / \mathrm{a}$. Despite the fact that the deep basin sector had a high accumulation rate $(0.25 \mathrm{~mm} / \mathrm{a}$, Fig. 5$)$, it records a net uplift rate of $0.31 \mathrm{~mm} / \mathrm{a}$. This can be explained by the palaeobathymetric evolution of DS-IIb, which began at $800 \mathrm{~m}$ and ended at $300 \mathrm{~m}$ (see Fig. 3).

The end-Tortonian tectonic event is characterized by an episode of rapid uplift that mainly affected the Villanueva de las Torres and Coto Cherrín-Dehesas de Guadix sectors. The former emerged, with erosion of DS-I and part of DS-IIa, and the latter underwent abrupt shallowing. The end result of this tectonic event was the deposition of shallow marine facies (DSIII) in most of the basin, with deltaic deposits (DSIIIb), platform deposits (DS-IIIc) and reefal deposits (DS-IIId). Sediments corresponding to depositional lobes built by debris flow and scree deposits were trapped in small pockets bounded by faults and located in the part of the basin remaining above sea level as a result of the rapid uplift (DS-IIIa). During the deposition of DS-III the marine basin did not subside actively, with maximum values in the Coto Cherrín-Dehesas de Guadix sector of $0.01 \mathrm{~mm} / \mathrm{a}$ total subsidence rate. The previously emergent Villanueva de las Torres sector continued to rise at a net rate of $0.01 \mathrm{~mm} / \mathrm{a}$.

Sedimentation of DS-IV began at the same time as the continentalization of the basin, which became clearly cut off from the sea. After this event an episode of general uplift began, whose rates range from 0.09 to $0.05 \mathrm{~mm} / \mathrm{a}$ in the Villanueva de las Torres and La Lancha-Negratín sectors respectively. The endMiocene tectonic event, which defined the lower boundary of DS-V+VI, did not alter the general trend of uplift that had already begun at the bottom of DSIV. During the deposition of DS-V+VI the total uplift rate was $0.1 \mathrm{~mm} / \mathrm{a}$ in the three sectors of the basin. The end result of the uplift stage characterizing DS-IV and DS-V+VI was the final-filling of the basin at $1000 \mathrm{~m}$ palaeoelevation in Late Pleistocene times.

\section{Conclusions}

Analysis of the sedimentary record on the northern margin of the Guadix intramontane basin allows us to define six depositional sequences (DS-I to DS-VI) whose boundaries were formed by tectonic events. Sedimentation began in the Early Tortonian with continental slope features $800 \mathrm{~m}$ deep and ended in the Late Pleistocene with a final-filling episode at $1000 \mathrm{~m}$ palaeoelevation.

Our quantification of subsidence and uplift is shown on geohistorical diagrams containing three curves representing the basin floor, tectonic subsidence and total subsidence. These data were obtained by decompacting the stratigraphic units and local isostatic backstripping, with corrections made for palaeobathymetry and palaeoelevation. The geohistorical diagrams show that most of the tectonic events coincided with significant changes in the trends of the tectonic and total subsidence curves. 
The most complete stratigraphic succession (Coto Cherrín-Dehesas de Guadix) shows a discontinuous episode of strong subsidence during DS-I, which formed a deep marine basin in the sector in question. After the boundary between DS-I and DS-II (the midTortonian tectonic event) the curves change their trend to uplift during DS-II. This stage of uplift led to the gradual shallowing of the basin as recorded in the sequence. The boundary between DS-II and DS-III (end-Tortonian tectonic event) is characterized by an episode of sharp uplift, leading to the introduction of shallow marine platform conditions throughout the basin. During DS-III there was no tectonic subsidence, and the total subsidence detected was simply the result of sedimentary load. The boundary between DS-III and DS-IV (continentalization) coincided with the beginning of an uplift stage that continued without significant alteration to the top of DS-V+VI (final-filling of the basin). We should point out that the boundary between DS-IV and DS-V+VI (end-Miocene tectonic event) is only recorded by a slight change in the slope of the total uplift curve, while the tectonic uplift curve remains constant. This can be explained by the fact that the deformation associated with the end-Miocene event was subordinate to the uplift that began earlier.

The most significant feature of the Villanueva de las Torres and La Lancha-Negratín successions is an episode of sharp uplift on the boundary between DS-I and DS-II (intra-Tortonian tectonic event). This was responsible for the complete erosion of DS-I in these sectors, possibly after a previous erosive stage. A stage of slight subsidence can be detected during DS-II causing the shallow marine platform conditions to remain throughout Late Tortonian times. The limit between DS-II and DS-III (end-Miocene tectonic event) was only recorded in the La Lancha-Negratín sector. It is defined by a decrease in the slope of the subsidence curves, indicating very low or no subsidence during DSIII. The beginning of DS-IV (continentalization) marks the start of a stage of uplift similar to that described for the Coto Cherrín-Dehesas de Guadix sector.

The results obtained by this research demonstrate the viability of tectono-sedimentary analyses with quantification of uplifting and subsidence in the central sector of the Betic Cordillera. We believe that the information on the geodynamic evolution of the area obtained in this case study justifies the application of similar analyses in other sectors of the cordillera.

Acknowledgements. This paper has greatly benefited by the suggestions of P. F. Friend and N. White. Study has been financed by the DGICYT, Project AMB95-1557 and by Research Group RNM0163 of the Junta de Andalucía.

\section{References}

Allen, P. A. \& Allen, J. R. 1990. Basin Analysis. Principles and Applications. Oxford: Blackwell Scientific Publications, 451 pp.
Andrieux, J., Fontboté, J. M. \& Mattauer, M. 1971. Sur un modèle explicatif d'Arc de Gibraltar. Bulletin de la Societé Géologique de France (7) 15, 115-18.

Angevine, C. L., Heller, P. L. \& Paola, C. 1990. Quantitative sedimentary basin modelling. American Association of Petroleum Geologists Bulletin, Continuing educations course note series 32, $132 \mathrm{pp}$.

Berggren, W. A. \& HaQ, B. U. 1976. The Andalusian Stage (Late Miocene): Biostratigraphy, Biochronology and Palaeoecology. Palaeogeography, Palaeoclimatology and Palaeoecology 20, 67-129.

Bond, G. \& Kominz, M. 1984. Construction of tectonic subsidence curves for the Early Paleozoic miogeocline, southern Canadian Rocky Mountains: implications for subsidence, age of breakup and crustal thinning. Geological Society of America Bulletin 95, 155-73.

Calvache, M. L. \& Viseras, C. 1997. Long-term control mechanisms of stream piracy processes in southeast Spain. Earth Surface Processes and Landforms 22, 93-105.

Calvache, M. L., Viseras, C. \& Fernández, J. 1996. Evolution from endorheic to exorheic drainage in the Guadix Basin: geologic and geomorphic implications. In 2nd Cortijo Urra Field Meeting, SE Spain: Field Guide (eds A. E. Mather and M. Stokes), pp. 43-8. University of Plymouth.

Cloetingh, S., Van der Beek, P. A., Van Rees, D., RoeP, T., Biermann, C. \& Stephenson, R. A. 1992. Flexural interaction and the dynamics of neogene extensional basin formation in the Alboran-Betic region. GeoMarine Letters 12, 66-75.

Comas, M. C. \& García Dueñas, V. 1988. Evolución de un segmento del Paleomargen Sudibérico. II Congreso Geológico de España, Guía de Campo de la Excursión $B-3,1-73$.

Comas, M. C., Zhan, R., Klaus, A. et al. 1996. Leg 161 Western Mediterranean. Initial Reports of Ocean Drilling Program 161, 1-638 (Washington: U.S. Government Printing Office).

De RuIG, M. J. 1992. Tectono-sedimentary evolution of the Prebetic fold belt of Alicante (SE Spain): a study of stress fluctuations and foreland basin deformation. Ph.D.Thesis, Publ. Vrije Universiteit Amsterdam, 207 pp.

Fernández, J., Bluck, B. J. \& Viseras, C. 1991. A lacustrine fan-delta system in the Pliocene deposits of the Guadix Basin (Betic Cordilleras, South Spain). Cuadernos de Geología Ibérica 15, 299-317.

FernándeZ, J., Bluck, B. J. \& Viseras, C. 1993. The effects of fluctuating base level on the structure of fan and associated fan-delta deposits: an example of the Tertiary of the Betic Cordillera (Spain). Sedimentology 40, 879-93.

Fernández, J., Soria, J. M. \& Viseras, C. 1996. Stratigraphic architecture of the Neogene basins in the central sector of the Betic Cordillera (Spain): tectonic control and base level changes. In Tertiary Basins of Spain: the stratigraphic record of crustal kinematics (eds P. F. Friend and C. J. Dabrio), pp. 353-65. Cambridge: Cambridge University Press.

FernÁndeZ, J., Viseras, C. \& Soria, J. M. 1996. Pliocene-Pleistocene continental infilling of the Granada and Guadix basins (Betic Cordillera, Spain): the influence of allocyclic and autocyclic processes on the resultant stratigraphic organization. In Tertiary Basins of Spain: the stratigraphic record of crustal kinematics (eds 
P. F. Friend and C. J. Dabrio), pp. 366-71. Cambridge: Cambridge University Press.

Friend, P. F. \& DABrio, C. J. (eds) 1996. Tertiary basins of Spain: the stratigraphic record of crustal kinematics. Cambridge: Cambridge University Press, $400 \mathrm{pp}$.

GAllagher, K. \& LAMBECK, K. 1989. Subsidence, sedimentation and sea level changes in the Eromanga Basin, Australia. Basin Research 2, 115-31.

García Dueñas, V., Balanyá, J. C. \& Martínez, J. M. 1992. Miocene extensional detachments in the outcropping basement of the northern Alboran Basin (Betics) and their tectonic implications. Geo-Marine Letters 12, $88-95$.

Gradstein, F. M. \& SRivastava, S. P. 1980. Aspects of Cenozoic stratigraphy and paleocenography of the Labrador Sea and Baffin Bay. Palaeogeography, Palaeoclimatology and Palaeoecology 30, 261-95.

Heckel, P. H. 1972. Recognition of ancient shallow marine environments. In Recognition of ancient sedimentary environments (eds J. K. Rigby and W. K. Hamblin), pp. 226-96. Society of Economic Paleontologists and Mineralogists Special Publication no. 16.

JABAloy, A., GALindo ZALdivar, J. \& GonZÁlez Lodeiro, F. 1992. The Mecina Extensional System: its relation with the post-Aquitanian piggy-back basins and the paleostresses evolution (Betic Cordilleras, Spain). GeoMarine Letters 12, 96-103.

Janssen, M. E., Torné, M., Cloetingh, S. \& Banda, E. 1993. Pliocene uplift of the eastern Iberian margin: Inferences from quantitative modelling of the Valencia Trough. Earth and Planetary Science Letters 119, 585-97.

Mitchum, R. M. JR., Vail, P. J. \& Thomson, S. 1977. Seismic stratigraphy and global changes of sea level. Part 2: The Depositional Sequence as a basic unit for Stratigraphic Analysis. In Seismic Stratigraphy (ed. C. E. Payton), pp. 53-62. American Association of Petroleum Geologists Memoir no. 26.

Sanz de Galdeano, C. 1990. Geologic evolution of the
Betic Cordilleras in Western Mediterranean, Miocene to the present. Tectonophysics 172, 107-19.

Sanz de Galdeano, C. \& Vera, J. A. 1992. Stratigraphic record and palaeogeographical context of the Neogene basins in the Betic Cordillera, Spain. Basin Research 4, 21-36.

SClater, J. \& Christie, P. A. 1980. Continental streching: An explanation of the post-mid-Cretaceous subsidence of the central North Sea Basin. Journal of Geophysical Research 85, 3711-39.

SORIA, J. M. 1994. Evolución sedimentaria y paleogeográfica durante el Mioceno Superior en el borde norte de la Cuenca de Guadix, Cordillera Bética Central. Estudios Geológicos 50, 59-69.

VAN HinTe, J. 1978. Geohistory analysis - Application of micropaleontology in exploration geology. American Association of Petroleum Geologists Bulletin 62, 201-22.

VerA, J. A. 1970. Estudio estratigráfico de la Depresión Guadix-Baza. Boletín Geológico y Minero LXXXI-V, 429-62.

VISERAS, C. 1991. Estratigrafía y sedimentología del relleno aluvial de la Cuenca de Guadix (Cordilleras Béticas). Secretariado de Publicaciones de la Universidad de Granada, 327 pp.

Viseras, C. \& FERnÁndeZ, J. 1988. Significado sedimentológico y tecto-sedimentario de la Formación Brechas del Río Gor. Cuenca de Guadix (Cordilleras Béticas). II Congreso Geológico de España, Simposios 299-308.

Viseras, C. \& Fernández, J. 1992. Sedimentary basin destruction inferred from the evolution of drainage systems in the Betic Cordillera, southern Spain. Journal of the Geological Society, London 149, 1021-9.

Viseras, C. \& FERnÁndeZ, J. 1994. Channel migration patterns and related sequences in some alluvial fan systems. Sedimentary Geology 88, 201-17

ViserAs, C. \& FERnÁndeZ, J. 1995. The role of erosion and deposition in the construction of alluvial fan sequences in the Guadix Formation (SE Spain). Geologie en Mijnbouw 74, 21-33. 